DOI https://doi.org/10.30525/978-9934-26-040-7-11

\title{
LEGAL FOUNDATION \\ FOR ACADEMIC INTEGRITY CULTURE IN UKRAINE
}

\author{
Patsurkivskyy P. P. \\ Student \\ Institute of Law of the Taras Shevchenko National University of Kyiv \\ Kyiv, Ukraine
}

Articulation of the issue. In summer of 1997 the paper «Ten Academic Integrity Principles for Lecturers» was released by the Centre for Academic Integrity at University of California (USA). These rules can be outlined as follows: to affirm the importance of academic integrity; to foster student's love for studying; to treat students as independent individuals; to establish the atmosphere of trust in the audience; to encourage students' responsibility for academic integrity; to formulate clear expectations for students; to develop fair and relevant forms of assessment; to limit the opportunities for academic dishonesty; to challenge academic dishonesty when such cases occur; to help define and maintain university-wide standards of academic integrity [1]. The abovementioned reasons turned into the valuable assets for both American and European academic cultures within a quite short period of time, and Ukraine made no exclusion either.

After the Revolution of Dignity the new horizons were opened to the issue of academic integrity as public benefit to Ukrainian academic environment. The prerequisite for the process was profound qualitative alteration in the national educational legislation. Particularly, education was attributed to the grounding of personality development, to guaranteeing the society development, united under sharing European values.

The research addresses the overview of the main aspects of normative reflection of this approach.

Constructing the Academic Integrity in Terms of Ukrainian Law «On Education.»In general, the law «On Education» jointly with the Constitution of Ukraine refers to the number of general legal acts regulating relationships in the branch of education. Academic integrity is regarded as «basic principles of public policy in the field of education as well as the principles of educational practices». The fundamental significance lies in the fact that the legislator attributed the adherence to academic integrity to the direct responsibilities of both, the students and the academic staff [2]. 
Considering the issue of academic integrity, Article №42 of the discussed law deserves for our specific attention since it addresses the interpretation of the principles of legal regulation of the academic integrity culture. The article offers the normative definition of academic integrity, which is approached by a legislator as «a set of ethical principles and rules defined by law, which should serve as the guidelines for educational process while instructing, teaching, doing a research (which belongs to creative activities) aiming at ensuring the results of the study process as well as the outcomes of the research conducted to be co confidence in learning outcomes and / or scientific (creative) achievements» [2].

The implementation of the above-mentioned goal is based on the state's comprehensive awareness of: 1) the importance attributed to education and science with their reference to social progress; 2) the crucial need for improving their prestige in the society nationwide; 3 ) the assurance of them to be seen as the trusted social institutions.

In the paper the major focus falls upon the contouring of Ukrainian legal matrices: a) adherence by the teachers as well as by academic staff to the academic integrity; b) following the norms of academic integrity by the university students; c) academic integrity violation; d) responsibility for academic integrity violation by teaching and academic staff; e) students' liability for breaching the principles of academic integrity; f) the types of academic responsibility; g) the procedure of identifying and uncovering the facts of academic integrity violation. Together, they formed the current legal structure of academic responsibility. This is a kind of Copernican revolution in the approaches of the Ukrainian state to the development of the legal foundations of the culture of academic integrity in Ukraine.

Implementation and Development of Normatively Fixed Legal Construction of Academic Integrity of the Law of Ukraine «On Education» by Special Laws of Ukraine. Considering the limited scope of this scientific research and the peculiarities of its functioning, the Laws of Ukraine «On Higher Education» and «On Professional Pre-Higher Education» provide the subject to the aforementioned analysis.

The legal construction of academic integrity was comprehensively implemented and developed in the special Law of Ukraine «On Higher Education,» which can be given a positive assessment in terms of its ability to establish a genetic link among the constituents of the legal matrix of academic integrity. Furthermore, the attribution of academic integrity issue to the main phenomena of higher education in the state deserves special attention due to the fact it has been done for the first time [3]. This is of crucial importance, specifically in conditions where a significant part of the 
national academic community, in general, and the students' community, in particular, considers the academic integrity to be a serious challenge.

By continuing and developing the concept postulated by the Law of Ukraine «On Education», the Law of Ukraine «On Higher Education» selects as its major focus and further pursues consistently an approach to the interpretation of academic integrity as a liability of all participants of educational and scientific processes. The abovementioned is particularly stated in articles 6, 19, 32, 58, and 63 of the Law. And Article 16 emphasizes that the abidance of academic integrity is also the duty of the higher educational establishment, and its structural subdivisions and other institutions [3].

An important innovation of the Law of Ukraine «On Higher Education» in the field of relations of academic integrity is the harmonizing of relations in this regard during the preparation of qualifying works and their protection. The legislator also outlined the liability for violation of academic integrity concerning the candidates for obtaining a degree as well as their supervisors or consultants, the official opponents, the members of specialized academic panels, together with the higher educational establishment respectively.

This provides the sufficient grounding for concluding that the created foundation for academic integrity in higher educational institutions can be already viewed as the one minimally required. Together with the regulatory directions of the Law of Ukraine «On Education», these legal bases are able to ensure effective legal regulation of academic integrity. Opposed to the previously mentioned, it is hardly working in practice or even does not exist, owing to an acute deficit for an adequate political will required from the state and political elite of Ukraine. In this realm of public relations, Ukraine is still between the «civilized» West with its advancement in the issue of academic integrity and postcolonial majority of the East of Asia.

A separate group of innovative legal norms was created by the domestic legislator within the framework of the Law of Ukraine «On Professional PreHigher Education». First of all, their novelty lies in the fact that they expend the sphere of specialized legal regulation of relations within academic integrity to a large array of educational institutions in Ukraine, which were not concerned about these issues earlier. This law and the two previously mentioned ones have the treatment of academic integrity «as a duty of all participants of an educational process in the educational institution» in common [4].

At the same time, the Law of Ukraine «On Professional Pre- Higher Education» contains a number of peculiarities in legal regulation of relations of academic integrity which makes it a progressive legal instrument. These features are set out mainly in Article 26 «Ensuring Academic Integrity in the 52 
Field of Professional Pre- Higher Education» of this Law. In particular, paragraphs 1, 2 and 3 of part 5 of the article legally establish three additional, in comparison with the Law of Ukraine «On Education», types of academic integrity violations: unauthorized cooperation; academic fraud; biased evaluation. Part 6 of this article provides for six new or significantly modified types of academic liability of teaching staff (scientific and pedagogical employees) of professional pre-higher education institutions and four new and five significantly modified types of academic liability of applicants for professional pre-higher education for violation of academic integrity. In the latter case, two thirds of the types of academic responsibility can be imposed only with the consent of the student government. Another innovation is that in accordance with part 9 of this article, «for failure to respond to violations of academic integrity, the head of a professional prehigher education institution may be subject to disciplinary action» [4].

Conclusion. Owing to the noticeable integration of higher education in Ukraine into the European educational space after the Revolution of Dignity, as well as to sharing of European civilizational values, significant shifts have taken place in the field of legal regulation of the culture of academic integrity of the state. Ukraine has created appropriate legislative conditions for practical implementation of European policies and practices of academic integrity by higher educational and other public institutions. An important means of guaranteeing these processes could be the policy of public-private partnership and the recognition of academic integrity as one of the strategic priorities of the state.

\section{References:}

1. Ten principles of academic integrity for teachers (Center of Academic Integrity). [Electronic resource]. - Access mode: https://saiup.org.ua/resursy/desyat-pryntsypiv-akademichnoyidobrochesnosti-dlya-vykladachiv-tsentr-akademichnoyi-dobrochesnosti/

2. Law of Ukraine «On Education» of September 5, 2017. [Electronic resource]. - Access mode: https://zakon.rada.gov.ua/laws/show/2145-19

3. Law of Ukraine «On Higher Education» of July 1, 2014. [Electronic resource]. - Access mode:https://zakon.rada.gov.ua/laws/show/1556-18

4. Law of Ukraine «On Professional Higher Education» of June 6, 2019. [Electronic resource]. - Access mode:https://zakon.rada.gov.ua/ laws/show/2745-19 